\title{
Editorials
}

\section{Leadership and management for all doctors}

The Doctor's frequent role as head of the healthcare team and commander of considerable clinical resource requires that greater attention is paid to management and leadership skills regardless of specialism. An acknowledgement of the leadership role of medicine is increasingly evident.' 1

\section{LEADERSHIP AS A COMPETENCE FOR ALL DOCTORS}

For the last few years leadership has been increasingly spoken and written about in the UK. High level reports looking at junior doctor training and the future of high quality clinical services have exhorted all clinicians to develop leadership skills during training ${ }^{1}$ and also in terms of future development of the NHS, clinicians having been described as being practitioners, partners, and leaders in health care. ${ }^{2}$

The Academy of Medical Royal Colleges and the NHS Institute for Innovation and Improvement developed the Medical Leadership Competency Framework $(M L C F)^{3}$ and its associated Medical Leadership Curriculum, ${ }^{4}$ which has now been endorsed by the General Medical Council (GMC) as a shared curriculum for all specialities in medical training across the UK. Rughani et al wrote of their experiences of integrating leadership into speciality training, ${ }^{5}$ describing how this added to the existing learning experience by enabling independence of thought, and sharing learning on how complex healthcare systems are and how difficult it can be to make change happen.

The National Leadership Council has now developed the Clinical Leadership Competency Framework (CLCF), ${ }^{6}$ which includes the competences from the MLCF but widens the context to include all clinicians and also added two further domains to recognise more specific competences that are needed by those looking to take on positional roles of leadership.

\section{GMC GUIDANCE FOR DOCTORS}

Explicit guidance for doctors who practise has been less clear, and until this year the GMC's advice was based on its document Management for Doctors. ${ }^{7}$ This guidance was intended to apply to all doctors but tended to be specific for those doctors in a management role. This guidance has now been superseded by Leadership and Management for all Doctors, ${ }^{8}$ reflecting the need for all doctors to understand their wider professional role as leaders and managers in the healthcare system.

This new guidance sets out clearly what doctors should do and what they must do; in terms of duties that apply to all doctors as well as those who have extra duties that fall within a designated position or role on management or leadership. It clearly states doctors must:

- engage with colleagues lall colleagues including doctors) to maintain and improve safety;

- contribute to discussions and decisions about improving the quality of services and outcomes;

- raise and act on concerns about patient safety;

- demonstrate effective team working and leadership;

- promote a working environment free from unfair discrimination, bullying, and harassment;

- contribute to teaching and training of doctors and other healthcare professionals including the need to act as a positive role model; and

- use resources for the benefit of patients and public. ${ }^{8}$

The document makes it very clear that all doctors need to show leadership, whenever they work in teams or interact with colleagues, and it is much more specific about how important it is to communicate information appropriately. In short it acknowledges that doctors do have a responsibility to patients as a first priority, but also have responsibilities to the health of the wider community, to all of their colleagues, and to the organisation in which they work.

\section{FUTURE DEVELOPMENT NEEDS FOR ALL DOCTORS}

What does this new guidance mean for GPs in the UK? It sets out clearly that while we are all here for our patients, we also need to recognise our role in the system in which we work. All GPs will need to reflect on how they develop skills in leadership and management in order to benefit the safety of patients and the safe running of the service they work in. Leadership cannot be left any longer to those doctors who do management', or who hold executive positions in practices, clinical commissioning groups, or primary care trusts. It also means that those in positions of senior management and leadership, whether in education, commissioning, or the regulation of services, will need to ensure that leadership skills are core and developed in all, and seen as part of clinical skills not as a separate course or optional extra.

There is already a huge amount of support for those who wish to develop their leadership skills. The Royal College of General Practitioners along with the other medical colleges, are developing strategies and aiming to increase awareness through educational support and signposting of events, both nationally and at faculty level. The First ${ }^{\circledR}$ GPs lan initiative to support new GPs from completion of training to the first point of revalidation at 5 years) hold regular leadership study days, and many deaneries have comprehensive packages enabling all their trainees to access leadership throughout their training. The Academy of Medical Royal Colleges has recently developed a joint faculty (Faculty of Medical Leadership and Management ${ }^{9}$ ) for all medical students, trainees, and doctors of any speciality to continue to support the development of knowledge and skills.

Funding for leadership development in the NHS is often seen as a means of developing skills for the next organisational

in practices, clinical commissioning groups, or primary care trusts. 


\section{"The challenge for any organisation that delivers or supports leadership development is to attract all comers and not just those that are already enthusiastic about participating and who have self-selected themselves.'}

change rather than a process developing a generic and core competence in all; for example, the leadership funding in primary care is currently earmarked around commissioning leadership at present. Leadership is much more than that, and needs to be able to empower all of us to inform and deliver organisational change at any level in the NHS, keeping patients and their carers at the core. Ritchie in his James Mackenzie Lecture in 2010 recognised leadership as being the ability to influence and motivate people, 10 describing leaders as those who can cope with change, and set vision and direction, stimulating team members to follow that vision. The challenge for any organisation that delivers or supports leadership development is to attract all comers and not just those that are already enthusiastic about participating and who have selfselected themselves. The GMC's new document puts these skills at centre stage for all doctors, challenging all of us to reflect on how we practise and how we lead.

\section{Veronica Wilkie,}

Senior Clinical Teaching Fellow, Institute of Clinical Leadership, Warwick Medical School, Coventry.

\section{Provenance}

Commissioned; not externally peer reviewed.

DOI: 10.3399/bjgp12X636290

\section{ADDRESS FOR CORRESPONDENCE}

Veronica Wilkie

Institute of Clinical Leadership, Warwick Medical School, Coventry, CV4 7AL.

E-mail: v.m.wilkie@awarwick.ac.uk

\section{REFERENCES}

1. Tooke J. Aspiring to excellence. Final report of the independent enquiry into modernising medical careers. London: Department of Health, 2008.

http://www.mmcinquiry.org.uk/MMC_FINAL_ REPORT_REVD_4jan.pdf laccessed $13 \mathrm{Apr}$ 2012).

2. Department of Health. High quality care for all. NHS next stage review final report. London: Department of Health, 2008. http://www.dh.gov.uk/prod_consum_dh/group s/dh_digitalassets/dadh/den/documents/digita lasset/dh_085828.pdf laccessed 13 Apr 2012)

3. Academy of Medical Royal Colleges. Medical leadership competency framework. Enhancing engagement in medical leadership. 3rd edn. London: NHS Institute for Innovation and Improvement and Academy of Medical Royal Colleges, 2010.

http://www.institute.nhs.uk/images/document s/Medical\%20Leadership\%20Competency\%2 OFramework\%203rd\%20ed.pdf laccessed 13 Apr 2012).

4. Academy of Medical Royal Colleges. Medical leadership curriculum. London: Institute for Innovation and Improvement and Academy of Medical Royal Colleges, 2011.

http://www.institute.nhs.uk/images/document s/BuildingCapability/Medical_Leadership/Med ical\%20Leadership\%20Curriculum.pdf laccessed 13 Apr 2012).

5. Rughani A, Godden A, Patterson D, Smithson $\mathrm{H}$. Training for leadership. Br J Gen Pract 2012; 62(594): 8-9.

6. National Leadership Council. The clinical leadership competency framework. Report on findings: summary.

http://www.nhsleadership.org.uk/images/libra ry/files/smallbooklet.pdf laccessed 13 Apr 2012).

7. General Medical Council. Management for doctors. London: GMC, 2006.

http://www.gmc-

uk.org/Management_for_doctors_2006.pdf_2 7493833.pdf (accessed 13 Apr 2012).

8. General Medical Council. Leadership and management for all doctors. London: GMC, 2012. http://www.gmcuk.org/guidance/ethical_guidance/11758.asp (accessed 13 Apr 2012).

9. Faculty of Medical Leadership and Management. www.fmlm.ac.uk laccessed 13 Apr 2012).

10. Ritchie L. James Mackenzie Lecture 2010. Beyond the numbers game - the call of leadership. Br J Gen Pract 2012; DOI: 10.3399/bjgp12X616472. 